\title{
"Crime-Talk", Security and Fear in the Countryside: A Preliminary Study of a Rural Irish Town and Its Hinterland
}

\author{
Artur Pytlarz \\ School of Languages, Law and Social Sciences \\ Technological University Dublin, \\ Grangegorman, Dublin 7, Ireland \\ Artur.pytlarz@mydit.ie \\ Matt Bowden, \\ School of Languages, Law and Social Sciences, \\ Technological University Dublin, \\ Grangegorman, Dublin 7, Ireland \\ Corresponding author: Matt Bowden: Matt.bowden@dit.ie; 35314024230
}

\begin{abstract}
Property and violent crime against older people in rural areas have become recurring themes in media representations of rural Ireland. This is also marked in the closure of rural police stations which might exacerbate the sense of abandonment amongst rural dwellers, hence, feeding a greater fear of crime. Top down crime-talk has stressed the need for 'smart policing' and state-led strategies have involved short, intensive policing operations to halt the mobility of urban based burglars; and a growing number of communities engaged in Community Alert Schemes and Text Alert Schemes. In this article, we report preliminary findings of our research conducted in a small rural town and the surrounding community in South-East Ireland. The research sought to capture crime-talk in a rural locale to reflect upon broader themes and identify issues for our ongoing research agenda. Data were obtained through a small number of in-depth semistructured interviews with members of the community. Our observations centre on the nature of adaptation to a felt sense of risk, fear and insecurity.
\end{abstract}

Keywords: rural security, crime-talk, crime prevention, late modernity, Ireland

ERRATUM (July 3, 2019)

Figure 1 (page 145) and Figure 2 (page 147) are corrected. 


\section{Introduction}

American rural criminological researchers Donnermeyer and DeKeseredy (2014) have noted that rural society worldwide is undergoing dynamic change. A decline in family farms is a common factor for rural communities in many countries and can be seen, in combination with dynamic changes affecting rural society, as a general expression of worsening life conditions. At the same time, there are global changes in security and crime prevention. Hughes (2007) argued that the relationship between both the state and community is also transforming: the structuring dynamics associated with late modern risk are challenging state capacity to act as the sole security provider. Policing is therefore pluralized and the task of crime control relocated to other bodies such as private actors, the community, and individual citizens.

This late modern turn, reflecting the so-called turn to neo-liberal crime control and its effects, has been variously characterized: a process of 'responsibilization', a transfer of former criminal justice state obligations onto private citizens (Garland, 2001) and reflecting a dispersal of central state power into the social body (Garland 2000; Ross 1999); a pluralization of policing (McLaughlin, 2007); increasing private security initiatives that should not be seen as a replacement of state police but rather as an addition to their numbers (Zedner, 2004); a 'rolling out' not a 'rolling back' of the criminal justice system (Hudson, 2001). These themes also reflect a wider concern in the last two decades with the onset of late modern society. The characteristics of late modernity are fluidity and recurring change in the nature of social and cultural life - lack of stability, increase of fear, decrease of the role of nation states, precarity in employment, the demise of traditional institutions - all underscoring the 'liquid' character of modern social life (Bauman 2007; Young 2007).

Reflecting on these broader themes and witnessing heightening public concern over rural crime and security in Ireland we sought to utilize this theoretical framework by developing a case formed upon the unfolding changes in rural Ireland. Rural crime and security in Ireland has taken a more central position in recent media and political discourses. During the general election campaign in 2016 for example, matters of rural crime and security were raised by incumbents and hopefuls alike (McGee, 2015). Indeed, the post-election landscape saw the balance of power potentially being held by ruralbased deputies in the negotiations for the formation of a government (Tierney, 2016).

Unlike in England, Wales and Scotland where devolution has been a driver of cost savings (Yarwood \& Wooff, 2016), Ireland is part of an external structural adjustment programme agreed between the Irish Government and the 'troika' - European Union (EU), International Monetary Fund (IMF), and European Central Bank (ECB). The first 
wave of public sector cuts involved the closure of approximately 140 police stations, many of them in rural areas. Media representations of a wave of rural crime, focused primarily on attacks on elderly farmers in isolated areas. The actual official crime rates for rural areas, however, remained stable, as outlined later in this article. Both austerity and a rising fear of crime are forging adaptations in rural Irish life. For example, the Irish Farmers' Association (2016) appointed a crime prevention executive to develop crime prevention policy and to roll out preventive initiatives.

We limit ourselves in this preliminary research to capture 'crime-talk' as best we can in a rural town and its hinterland in Ireland. 'Crime-talk', which affects perceptions of community safety and general wellbeing, is a symptom of social conflict which can be observed in times of transformation and social change (Carrington, Hogg, McIntosh \& Scott, 2012). Therefore, it can be easily connected to the wide range of anxieties and fears experienced by members of a community. For Scott, Carrington and McIntosh (2012 p.148) 'crime-talk provides a valuable insight into the construction and policing of rural social order'. Yet 'crime-talk' shouldn't be seen as a discourse about criminal activity: it concerns the drawing of social boundaries that constitute community. 'Crimetalk' defines what behaviours, groups or individuals should be seen as deviant and which of them are considered the most dangerous for the safety of a community. Thus 'crimetalk' becomes the evidence about how crime and deviance are constructed in a rural setting. At the same time, Hogg and Carrington (2006) argue that crime-talk in rural settings tends to ignore interpersonal violence and emphasises crime against property which can be observed in images portrayed by mass-media in Ireland. Therefore, it is a complicating factor surrounding empirical research on the nature of rural crime and the experiences of individuals and communities in that context.

In this article we briefly outline the wider literature reflecting on the emergence of crime prevention as a late modern phenomenon and consider its application to the case. Secondly, we outline the emergence and prominence of rural crime and security in public discourse as a direct result of rural transformation between two forces: rapid and accelerated modernization (Keohane \& Kuhling, 2003) in the global era; and the countervailing power of austerity after the economic crash since 2010 . Thirdly, we outline the key themes identified in our preliminary study in order to set the agenda for further thinking and fieldwork.

In this early stage of our larger ongoing study, we conducted a small number of focused interviews with rural dwellers in Janusville ${ }^{1}$ to quickly capture the crime-talk of its residents. We were initially interested in why members of rural communities join (or not) crime prevention schemes, how they experience victimization, and how they see themselves in the process of producing security. We draw from the insights of our 
participants in our discussion the nature of transformations and adaptations to crime. The small scale of the project and the issues of access, made a short, rapid field engagement our only viable option and made the Crime-talk approach more attractive

Access to the site was complicated by the reliance on a gatekeeper organization, an NGO working in rural areas who were unable to meet with our criteria for fast access. In choosing the site, we also wished to ensure that a police-supported Text Alert crime prevention scheme was in operation. Working through personal contacts the fieldworker made a link with Barbara, a woman living in Janusville, a rural small town with a large agricultural hinterland. The field researcher used a snowball sampling approach and was quickly put in touch with Ann a small business owner. Between these two primary contacts, the field researcher was able to identify a further four participants and a total of six field interviews were carried out.

We collected our data in the form of guided semi-structured interviews. All respondents were asked to address six discussion topics which were designed to encourage respondents to construct their own Crime-talk narratives based on their knowledge and experience. They were asked to:

- Describe the general experience of living in Janusville;

- Identify what changes they have identified in the town and countryside;

- To talk about crime and victimisation in their community;

- To describe what do they do to ensure their own safety and that of their relatives;

- To explain their reasons for joining (or not joining) the Text Alert Scheme;

- Give their own evaluations of the Text Alert in general.

A fuller summary of the approach to the research is outlined in our concluding section, together with a discussion of Crime-talk as theory and method.

\section{Crime, Fear and Late Modernity}

One of the most significant social developments of recent years is the transition from the modern to late modern. Newburn (2013) identified one of the main features of late modernity as the global nature of capital and business, where national governments and local governors have relinquished a degree of control and sovereignty over both. At the same time there is the bottom-up pressure on the state from the local communities to prioritise local crime issues, often with an authoritarian flavour (Stenson \& Lea, 2007). These two features shape the field in which the state operates and can be seen as undermining its role. In the area of governance of security, it can be observed in the number of the private agencies and non-state bodies involved in the process, who operate 
side-by-side with official police (Shearing \& Wood, 2003). The growth of non-state bodies involved in governance makes it more difficult to maintain the vision of a statecentred structure of power: a centralised system is replaced by nodal governance, involving a mix of state, enterprises, and non-governmental organizations (Shearing \& Wood, 2003 p. 405). Nodal governance is less rule bound governing, is the antithesis of bureaucracy as it works through relationships and processes, rather than procedures and hierarchical arrangements of offices. Hence, late modern security governance entails networked configurations with a tendency to decrease the position of the state.

Characterising late modernity, Beck (1992) argued that Western cultures have moved from first modernity (which was relatively predictable and controllable) into a second modernity or risk society characterized by its global mega-hazards (which potentially escape governmental regulation). Beck argued further that the expanding process of individualization moves the burden of risk management from the system (state) into the life-world of individual decisions (Mythen, 2014 p. 29). This shift has echoes in the work of Garland (2001) who pointed out that crime prevention, especially in the Anglo-Saxon world, reflected a rediscovery of the situational actor of utilitarian thought - the individual, self-calculating actor who minimizes self-exposure to harm. In social policy terms such an actor could self-govern, irrespective of the state. Indeed, authors such as Rose (1999) suggested that the rise of crime prevention constituted a new ethical politics of self-discipline as an adaptation to the demise of the welfare state.

Bauman (2007) offered a different angle in the analysis of risk society. For him people become overwhelmed by the fast pace of social change while at the same time facing global risks such as terrorism or climate change. As they are not able to predict or control the direction of changes in their surrounding world or do anything about global hazards, they turn to consumption to deal with their fear as this has been commodified for profit, for those who can afford it, that is, those who can't are 'flawed consumers' (Bauman 2007). This contrasts with Beck who believed that the stratifying logic of the risk society was horizontal which means that both rich and poor will be equally affected by the global hazards (Mythen, 2014 p. 30). To place that argument in a criminological context it has to be noted that as safety becomes a product and is only available for some: crime prevention can be seen as a way of redistributing crime from those who can afford better locks, better alarms or simply a house in a better, safer neighbourhood (Hope 2009, p.53).

In moving to study rural crime and security we have struggled to link these narratives of late modernity to a focus on the nature of rural transformation. Donnermeyer and DeKeseredy (2014), in their analysis of the rural U.S., point to the decline of family-owned farms, population mobility, urbanization and an expanding 
transportation grid as factors of worsening living conditions for rural communities. Therefore, the problem of crime in the countryside escapes one simple definition and transplanting urban definitions should be avoided.

Donnermeyer and DeKeseredy (2014) offer an analysis of the myths in respect to rural crime. The first of these myths relates to the urban-rural dichotomy. The source of that myth lies in an assumption that rural communities are more homogeneous, thus should experience lower rates of crime. Yet 45 percent of the world's population lives in rural contexts and they exercise a variety of behaviours that are both law-abiding and deviant or criminal. The second of these myths relates to the assumption that collective efficacy (greater capacity for collective social control) results in low crime. They argue that social organization, which can be seen as a force in reducing some types of crimes in specific rural settings, may facilitate other types of crime. For example, a tight-knit rural community may be resistant to property crime but the same mechanisms of social control may prevent victims of domestic abuse from reporting that crime at all due to the prevailing dominance of patriarchal relations in rural family and kinship structures. The third of these myths relates to rural crime rates being historically low and only now increasing. That myth is related to the pastoral image of the rural as an historical place of peace and order.

Donnermeyer, Scott and Barclay (2013 p.83) suggested that crime in rural settings can be examined by the nature of 'crime-talk', how rural dwellers talk about crime. Thus if press coverage can be seen as extension of crime-talk, it highlights the dominant problems for inhabitants of rural communities in Ireland. Bearing this in mind, our attention turned to the fear of crime as a complex phenomenon defined as a 'rational or irrational state of alarm or anxiety engendered by the belief that one is in danger of criminal victimization' (McLaughlin, 2013, p.175). Burney (2005) in her study of antisocial behaviour came to the conclusion that the fear of crime is distinct from measurable crime rates. Ross, Mirowski and Pribesh (2001) argue that the fear of crime relates to the sense of powerlessness strengthened by signs of disorder. Additionally, fear of crime can relate to direct experience, secondary knowledge from family members, friends or neighbours. A separate but important role is played by news media (McLaughlin, 2013).

The last theoretical category guiding our research was responsiblization - a term used by Garland (2001) to describe a situation where government recognises the limits of its power as a provider of order and safety. Derived from Foucault (1977), Garland uses this term to denote the way in which the state disperses power away from the centre toward the periphery and in effect extends rather than reduces the pastoral and panoptic power of the state. Therefore, the task of crime control is transferred to other public and private actors. At present responsibilization should be seen as a way of encouraging 
communities to share responsibility for their own wellbeing, through involving them in creating local safety strategies and local safety partnerships (Zedner, 2004). It is more about recognising a problem and solving it than about inflicting sanctions if the problem still occurs. Public participation is a matter of good will and not obligatory. An example of this in our case is the Text Alert Scheme ${ }^{2}$ in Ireland, which has approximately 100,000 voluntary members. As Zedner (2004) argues, such mobilizations should not be seen as a simple transfer of responsibility onto non-state bodies, but the extension of state power.

\section{The Context: Crime, Modernity and Change in Rural Ireland}

Irish rural social structure endured a series of changes in the last century. In their classic anthropological study of rural social structure in Ireland during the 1930s, Arensberg and Kimball $(1940,2001)$ noted that 61 percent of the population in 1926 lived in the countryside and almost 51 percent of the working population were engaged in some form of agriculture. Ninety years later the rural population comprises 37.8 percent of the total and there is a noted downward trend in the number of family farms, from 141,527 in 2000 to 139,829 in 2010 (Central Statistics Office, 2010a). Geographical researchers have noted that between 1991 and 2011 the number employed in the agricultural sector in Ireland fell by 67,000, and industrial restructuring was unevenly distributed between urban and rural areas (Meredith \& Faulkner, 2014).

In his account of the small town of Ballivor in the Irish midlands, Inglis (2008) analysed the impact of global changes on the social structure of this community. He noted how the village population grew from 287 in 1971 to over 1,500 in 2006: most of the newcomers commuted to Dublin as the adjacent global node. This glocalization of Ballivor and its rural hinterland, restratified the village into the established villagers and commuters: two groups who occupy the same territory but have little need to interact which each other. The commuters and their children were seen by established villagers as those who brought crime and disorder.

The issue of rural crime sits alongside the dualized narratives of rural decline and rural resilience (see Warburton, Scharf, \& Walsh, 2016). While declining in number for example, isolated rural pubs have, through their owners' social capital, shown to be steadfast and critical in generating economic development (Cabras \& Mount, 2015). While the economic downturn negatively impacted the laissez-faire housing system, rural in-migration involving a mix of urban blue-collar workers and returning migrants has nuanced the nature of urban housing expansion despite the existence of the deregulated conditions for promoting rural gentrification (Gkartzlos \& Scott, 2012). In addition, rural 


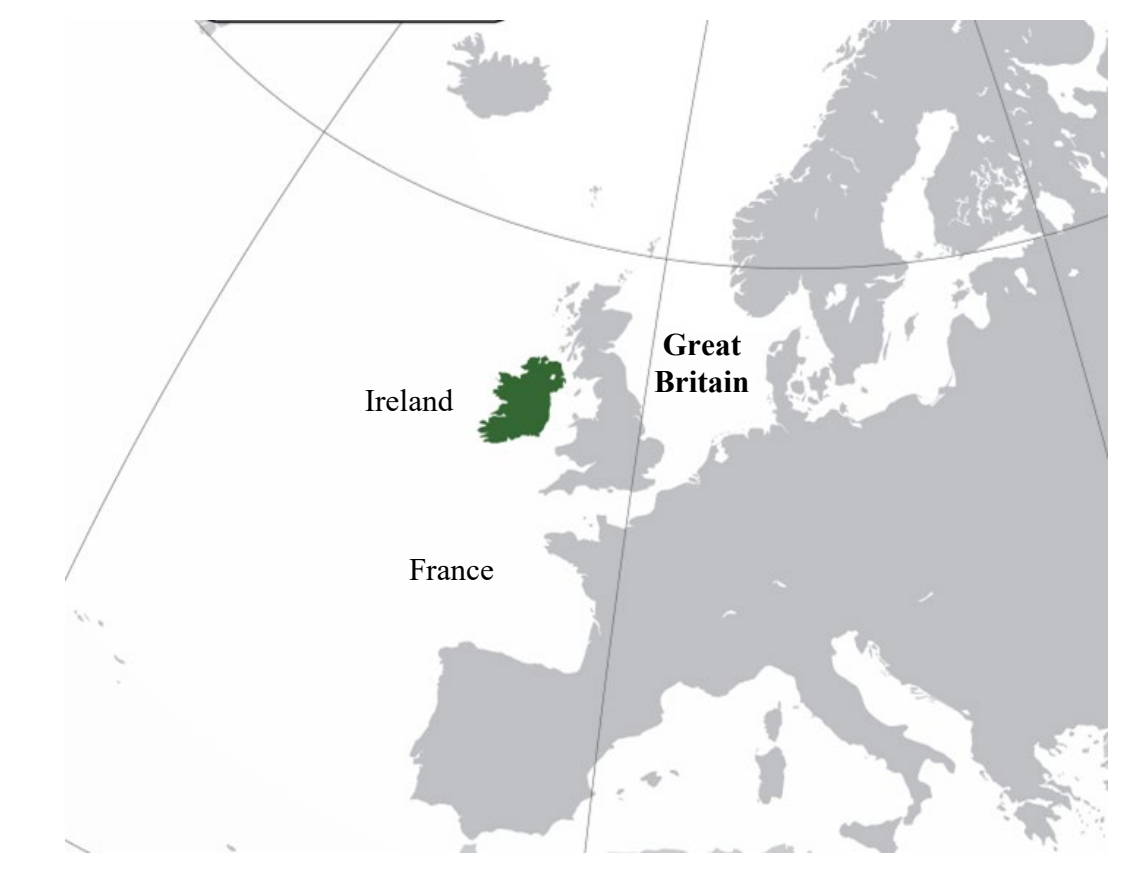

Source: Rob [CC BY-SA 3.0 (https://creativecommons.org/licenses/by-sa/3.0)] Labelling: Authors

\section{Figure 1: Ireland in Europe}

homeowners have shown to be comparatively more resilient and less burdened by mortgage debt during the economic downturn, in contrast to urban households (Murphy \& Scott, 2013).

Symbols of rural resilience and defiance have become a noticeable feature in the contemporary rural landscape. One of the new features which can be spotted by visitors travelling through contemporary rural Ireland is a sign informing them that the village, local community or town is part of a Text Alert Scheme (TAS). The scheme was set in motion in 2007 involving the police service An Garda Síochána ${ }^{3}$, Muintir na Tire (a rural community development organization) and the Irish Farmers' Association. It is a relatively low-tech crime prevention initiative where SMS messages are transmitted to community members. By 2015, promoters reported that over one million messages had been sent through the scheme (D'Arcy, 2015). The scheme sits alongside other official crime prevention strategies, including the Neighbourhood Watch in urban areas and the Community Alert Scheme (CAS) in rural areas.

Analysing the problem of crime in Irish rural settings reveals a number of intersecting dimensions in respect of official rates reflected in police data, victimization 
studies, media constructions and the fear of crime. Central Statistics Office (CSO) data revealed that in 2006, only 3.3 percent of people living in rural locations experienced crime in comparison to 5.4 percent of people who live in urban locations. Rural dwellers are less likely to become victims of violent crime, only 0.5 percent experienced physical assault, at the same time in urban areas that figure was 1.5 percent (CSO, 2007). ${ }^{4}$ Furthermore, people who are distressed by crime most are less likely to be victimized. For example, according to the Crime and Victimization report from 2010 in Ireland, people over 65 years old constituted the least victimised category among the whole population (CSO, 2010b, p.2). At the same time, they feel that they are very unsafe, 14 percent compared to 2 percent of 18 to 24 years olds (CSO, 2010b, p. 14).

While research in this field is scant, an evaluation of Neighbourhood Watch and rural Community Alert Schemes (CAS) in Ireland from 1998 revealed that only 3 percent of organisers of such schemes felt that crime was a serious problem in the scheme's area of operation. At the same time 44 percent felt crime was not a problem at all (McKeown \& Brosnan 1998 p. 37). Similar results are shown in a study from 2009, fear of crime was not associated with participants' involvement in Neighbourhood Watch and Community Alert Schemes. It was only important for 36 percent of those involved (Department of Justice, 2009, p.66).

Complicating the picture further are media portrayals of crime in rural Ireland that have constructed a sustained and menacing attack on quiet rural communities by urban based, mobile criminals: "Rural Ireland under crime siege" (O'Hagan, 2012); "Crime surge leaves rural Ireland in total despair" (Cusack, 2013); [police cuts] "leave rural Ireland at risk of crime" (MacConnell, 2012). Between these media representations of the 'attack' on rural communities and the low crime rates evident in official data, we presumed the lived experience of crime and fear of crime might reveal a more nuanced picture given the disjunctions between the media driven discourse, the apparent resourcefulness of rural communities, and the lived experiences of crime in every day rural life. A critical dimension to the structuring of rural security is the question of the fear of crime as a set of cultural constructions generating the 'grudge purchase' of security goods (Goold, Loader \& Thumala, 2010). As Lee (2007, p. 168) points out, "security apparently secures our security, and yet we continue to feel insecure the more security we secure. Simultaneously, fear and anxiety become part of an economy of insecurity; needs, or 'bads' to be serviced." 


\section{The Case: Crime-Talk in Janusville}

The study was designed to speedily capture crime-talk in one rural locale to inform our ongoing research programme on rural crime, fear, and resilience. We set in train a short series of in-depth interviews to access residents' everyday life experiences, feelings and attitudes towards issues (Cohen et al, 2011). We accessed participants through a personal contact who was the owner of a service business in Janusville, a small town nestled in a wide rural hinterland in the South East of Ireland. From there we took a small snowball sample and in all, six participants were willing to take part; four women and two men. One of our participants lived in the centre of Janusville itself and the rest were situated in surrounding countryside in its hinterland.



Figure 2: South East Ireland and Janusville in relation to Dublin

Source: Island_of_Ireland_location_map.svg: Rannpháirtí anaithnidderivative work: NikNaks [CC BYSA 3.0 (https://creativecommons.org/licenses/by-sa/3.0)]. Map labelling: Authors. 
Janusville is located almost 20 kilometres from a main national road route. The nearest regional centre to Janusville is Carlow, half an hour drive away. The town is located far enough away from Dublin to be rural and yet near enough to commute to the southern outskirts of the city within an hour. Carlow and the South East region were once at the centre of the sugar beet industry, now closed as a direct result of EU agricultural policy reforms and system of quotas (Chaplin \& Matthews, 2005). Janusville is therefore both rural and post-industrial in this sense and can be seen as an example of impact postFordist economics within international and global regulatory systems on rural Ireland (Meredith \& Faulkner, 2014). The population of Janusville district is just below 1,500. Between 2008 and 2011 there was a growth in population of 50 people (CSO, 2011). The town and surrounding areas had never experienced the rapid property boom related to the period of the Celtic Tiger. ${ }^{5}$ Janusville avoided having one of the 2,846 so-called ghost estates (Kitchin, O’Callaghan \& Gleeson, 2012), unfinished housing construction sites left behind as property developers' businesses collapsed during the recent property crash. Janusville has a primary and a secondary school, two churches: Roman Catholic and Church of Ireland (Anglican); and one Community Centre. The remoteness from services experienced by residents of Janusville adds to a sense of being disadvantaged. Untypical of rural Ireland, there is no $\mathrm{GAA}^{6}$ club in Janusville.

\section{Recorded Crime in the Janusville Garda District and Regional Crime Victimization}

Janusville is part of a wider district that takes in other rural areas, small towns and villages. Over 13 years from 2003-2015 the average number of reported crimes in the district was 253, ranging from 198 to $332 .{ }^{7}$ Looking at the distribution of reported crimes over the same period (Table 1), burglary and theft account for more than half of reported crimes, the remainder comprised in the most part from property related and public order based offences, with lower recorded data for crimes such as assaults, harassment, threats of violence, kidnapping. The Central Statistics Office, as a special module of the Quarterly National Household Budget Survey, has published occasional data on crime victimization. Disaggregated data for the district is unavailable, limiting our analysis to the South East region based upon the years 2003, 2006 and 2010. According to the report for 2010 the number of households in the South East that experienced any crime was 7 percent, compared with 9 percent nationally. Property crime in the region appears to be approaching a 'normal social fact' (Garland, 2001). Data for the period 1998 to 2006 revealed a declining trend in the reporting of property crimes to the police in the region while trust in the police appears to be strong with 71 percent of respondents rating the Gardaí as either 'good' or 'very good' in 2010. 
Table 1: District level reported crime data, average distribution 2003-2015

Official Crime Category
Mean distribution for the period \%

6.93

0.73

23.17

27.87

1.32

4.28

0.77

15.66

11.77

1.48

100.00

Source: Crime data series, Central Statistics Office, Ireland www.cso.ie

The general picture on feelings of safety reveals that most people in the region feel secure either in their neighbourhoods or at home. Ninety percent of respondents in the region reported that they felt safe in their own homes in 2010 and 72 percent said they were safe walking alone in their neighbourhoods. Over time it can be shown that the South Eastern region perceives crime as a more serious problem compared to Dublin where recorded crime and victims are actually higher (CSO, 2007, 2011).

\section{Crime-Talk and Memories of the City}

Ann and Barbara are not native to Janusville and are typical of residents who moved there from Dublin. For Ann, arriving in Janusville seven years ago, the main difference was the fact that there was much more togetherness within the community. She emphasised the fact that everybody knew each other and that for her was a sign of good community spirit. It was not always without problems. As Barbara, 70 years old and retired, living eight years in the community reported: 
It's taken me a long time to get accustomed to it, because being in Dublin for 40 years it was a big step for me to go down to Janusville. (...) I don't think Janusville has much to offer.

Barbara says she was too busy to contemplate doing things like evening classes in Dublin, but Janusville had an easier pace of life, which she had eventually come to accept.

People who have lived in Janusville and are established villagers, defined their experience of living in the community through the disadvantages they face in everyday life. For Dermot (37) it was a constant feeling that the community was going downhill. He sees that in the fact that the bank, one of the pubs, and the tennis courts are gone. Cecilia, a 50-year-old civil servant pointed to the general lack of facilities for young people and lack of a GAA club. Eddie (22) the youngest of our participants, emphasised the isolation and loneliness as a main feature of living in the countryside, which are stressors very often absent from urban settings (Evans, Smokowski \& Cotter, 2014). As he said in a sad tone: 'It is harder to make new friends when you're living in the country'. Illicit recreational drug use has become a more prevalent feature of regional rural life in Ireland (van Hout, 2009). Reflecting this change, Eddie noted that the use of illicit substances was replacing "traditional" drinking. For Cecilia the most influential change was the fact that Janusville has become a poorer town. She also pointed to the closure of the Garda Station. Eddie noticed that the ties in the community are getting weaker as the members are focusing on their own lives and good relationships with others erode.

'I think people don't look out for each other the way they used to. (....) People are going more selfish.'

We read these stories as representations of two Janusvilles, two faces of the same place where the ex-Dubliners refer to the benchmarks or memories of a more busy and less cohesive social order. The established villagers' story is that of decline, encapsulating a perceived change: crime, nuisance behaviours such as drugs and drinking in the town, are perceived markers of this change, as if they sense that the urban is encroaching upon the rural. In this vein, participants reported a rise of crime as the biggest problem in their community. Almost all of them mentioned widely available drugs, drinking misbehaviour, and vandalism. Fiona explained that in her view crime was caused by a greater number of "strangers" moving to the neighbourhood. As she said "no one knows who their neighbours are'. Many reported incidents that would be classified as minor, or as antisocial behaviour such as beer cans on the street, or vandalised cars. 
Ann, who spent more than half of her life in Dublin before moving to Janusville, was in disbelief that it could be like what she left behind. As she observed, almost every weekend young people would come to town to socialise. Yet often those social events would turn in to regular fights. Ann said that "when I first moved down I was like oh my God!? (...) I have to say, I was just completely shocked [by this] Neanderthal behaviour". Dermot, alluding to the absence of a police station added: "we had a guard here 7-8 years ago. There was no trouble whatsoever".

\section{Participants' Experiences with Crime, Police and Security}

Burglary was a common crime experienced by the participants and Cecilia who has lived for 18 years in Janusville was burgled on two occasions. Fiona, a 37-year-old florist, reported that in her case it was some jewellery with more sentimental than monetary value. Furthermore, Fiona emphasised that the whole situation was even worse because of the lack of official action:

'.... there was no follow up. We never heard anything. We never got anything from the local Guards after, they never said they were found (perpetrators), they weren't found. Nothing at all.'

Dermot who lives in town, described how he was attacked during a row in the pub. Even though he knew his attacker he never reported the incident to Gardai, adding that 'I didn't press any charges (...) I got threatened by about 20 people in town'. He described here the structuring of the power of reprisal which prevents people from reporting this type of occurrence to the official agencies.

Despite these accounts, our participants in general regard Janusville as a safe place to live. For example, Fiona saw her past victimization as a random event '... it's safe otherwise. It's just; it's just one of those things. It could've been the neighbour, not our house. It was a ... just the way happened it was our house, not their house'.

Similarly, for Dermot who lives in town, it is safe place to live: problems, as he saw it, were caused just by ten people which is a small proportion of the whole community, therefore crime may not be the central issue but fear in respect of a small group of people who are perceived to commit it.

Safety, fear, and security appear to be a highly nuanced as an experience for our participants and are tied to biography and geography: where you live in relation to the village centre. For example, Eddie told us that the rural parts of the district are much safer than Janusville itself; he wouldn't leave his bike outside a house in town as it could get 
stolen, when that's not a case in the rural part of the community. Barbara, a 70-year-old who thought that her isolation and a lack of close neighbours who could react in case there was something wrong at her home, was the biggest factor affecting her fear of crime. As Eddie put it:

'The only thing about the country is if your house has been robbed. People would hear the alarm go off and still walk by it, still drive by it, they would never [stop].'

In Janusville safety appears to result from doing something about one's security. Adapting to fear and isolation involved a range of personal and household strategies the most common of which was the use of electric gates and electronic alarms. The only exception was Eddie who does not own a property yet. Fiona had a close neighbour who watched her house and who came down and checked when she wasn't there. Barbara had two dogs as an extra safety measure. For her all these things were to protect her but also to create an image of safety. Barbara points out: 'I feel safe in Janusville because I have all the security things that make me feel safe. Or make my mind easy'.

Dermot who lives in town had installed CCTV cameras and a sensor on the side of his house. Due to his profession as a deer-stalker he owns seven guns ${ }^{8}$ : he had to install them to protect the guns from being stolen. At the same time the fact he owns firearms made him safer, as he described it:

'I think actually there was like new legislation introduced this year and you actually can shoot an intruder in this country. You can now, you can't in the past. (...) I have four kids so I'm not gonna hesitate [to use them].'

Apart from protecting their property, some participants expressed their strategies to ensure personal safety. For Eddie it was to avoid all potentially dangerous situations - he described how he learned to avoid certain parts of Janusville while Dermot's strategy to deal with any dangerous situation was self-defence and physical fitness:

'I took up the gym maybe 3 years ago. Start getting bigger myself, start feeling more (...) myself. I was also doing kickboxing. If I walk into town and getting into any trouble, I can walk out, where I'm not gonna be [a victim].' 


\section{Being part of a Text Alert Scheme}

Most of our participants were members of the Text Alert Scheme while those who were not members pointed to its weak points. Eddie for example took the view that the scheme provided information that wasn't important for him as that kind of criminal activity didn't bother him at all. Fiona pointed out that there was a tendency to exaggerate minor incidents:

'I've seen the texts my mother in law gets and to be honest (...) everybody is suspicious. If you drive down twice, you're suspicious (...) 'a suspicious white van', 'a suspicious red car' (...) it's always a red car.'

Amongst people who joined the scheme there was a clear division in views about its utility. Established villagers viewed it as not very effective, not useful and prone to exaggeration. Cecilia reported that the scheme was operating during certain hours (day time) thus she was anxious about the time the system was off. On top of that, during its hours of operation she was usually working in Carlow.

'I'm normally in Carlow anyway, so there's not a lot I can do with text here in Janusville. Even if I get a text about a van or a car.'

For Dermot the scheme was a complete waste of time as he pointed out that people were afraid to call 999 if they witnessed a crime in fear of reprisal so the whole system was faulty in its foundation. In contrast, Ann and Barbara who moved into the area fairly recently found TAS to be a good thing. They emphasised that the texts made them more vigilant: involved in observing movements in the community; and more aware of personal safety issues. For Barbara it was vital as thanks to texts she was able to close her electric gate every time there was a stranger reported in the vicinity.

\section{Emerging Themes and Issues}

Janusville is a rural locale through which global processes flow and it is a locale of contrasts. Wells and Weisheit (2004) and Ceccato and Dolmen (2011) argue that patterns of property and violence crime are not homogeneous and often differ within a rural community. Crime-talk as we captured it in Janusville indicated that the more rural part of the area was characterised almost exclusively by property offences such as burglary or car theft, whereas violent and public order offences were mostly associated with the town. 
Crime-talk in Janusvile is also Janus-like in respect of differences between those originating in the area and those who have moved from the city - those with ex-urban memory. This is similar to that observed in Inglis's (2008) ethnography of the glocalized rural town of Ballivor which was equally divided between native villagers and the more globalized, commuting newcomers. The divided narrative reflects Donnermeyer's and DeKeseredy's (2014) 'rural idyll' [Janusville is a peaceful place to move to] and 'rural horror' [Janusville is going downhill]. Looking at the strong micro level themes that emerged in our data, victimization, fear of crime, the role of police presence and situational protection strategies were prominent. We outline some of these issues before concluding with a reflection upon more abstract themes.

\section{Victimization and Fear of Reprisal}

Reflected in their crime-talk, victimhood and witnessing crimes were prominent features of the rural experience for our participants, despite the victimization survey data for the region showing no divergence from the national figures. The Crime and Victimisation Survey (CSO, 2010b) suggests that 75 percent of victims of burglary and only 64 percent of victims of assaults report these incidents to the police. One possible reason for the lower level of reporting of these categories of crime, which forms a working hypothesis for ongoing research, and relates to the fear of retribution from offenders or their associates within the community. Donnermeyer and Barclay (2005) observed that in case of close-knit rural communities in Australia, fear of being branded as a "snitch" was enough to prevent a member of the community from informing on the person to the police. Therefore, DeKeseredy, Donnermeyer and Schwartz (2009) suggested that the cohesion and social control in specific rural settings may in fact prevent local residents from reporting crime. Somerville, Smith, and McElwee (2015) have pointed out that illegal activity is often covered by the notion of a rural idyll as a crime free place. Websdale (1998) in his study of domestic violence in Kentucky described that mechanism as a powerful 'ol' boys network'. Another reason affecting lower level of reporting to the police can be previous victimization experience. For Fiona who became a victim of burglary, the poor response from the Gardaí to the crime and lack of the follow up was more traumatic that the material loss. Conaway and Lohr (1994), based on a longitudinal study, reported that previous victimization experience including reporting to the police, influenced greatly the level of reporting, especially where there was a repeat victimisation.

\section{Police presence}

The crime-talk revealed by our group shows their concern for the lack of police presence especially for the established residents. The belief is that they make a difference 
to safety in the area. Popular views of the function of the police suggest that they act as guarantors of security and safety (Jackson \& Bradford, 2009) and are there to apprehend potential offenders (Chalfin \& McCrary, 2012). The closure of the police station and the sense of abandonment has to be viewed together with the withdrawal of other institutions such as the bank and the absence of public transport. These features contribute to the sense of (in)security in Janusville and its surroundings as reflected in national print media coverage on rural Ireland (O'Hagan, 2012; Cusack, 2013; MacConnell, 2012). While those we interviewed understood that crime was low, police presence had a symbolic impact for community members, to reinforce the community's sense of cohesion, social control and civility (Jackson \& Bradford, 2009; Takahashi, 2010).

\section{Fear of crime}

Gerber et al. (2010) suggested that fear of crime is a multidimensional phenomenon triggered by local and global factors. Indeed, Swedish researchers suggested that overall anxieties and fear of crime may be more of a problem in rural areas than actual crime (Ceccato \& Dolmen, 2013, p.92). Amongst global factors reported by Janusville dwellers is the expansion of the road transportation network and therefore the transformation from remote to accessible. The crime-talk reveals stories of strangers coming to commit crime or to sell goods stolen elsewhere. Giddens (1990) had referred to the phenomenon of foreshortening time where distant incidents seem to be happening here and now - which structures a sense that crimes reported in distant parts of rural Ireland are happening in the here and now.

In local crime-talk, experiences with previous victimization, significant local crimes and rural isolation were easily identified as factors affecting fear of crime. For example, participants shared the same story in which a store was burgled, and a window in the pub was smashed. Unlike Bell (1997) who suggested that rural communities tend to blame outsiders as a source of crime and disorder, residents of Janusville pointed the finger equally at strangers and locals: local youth in particular are singled out as the source. Similarly, Somerville et al (2015) in their study of the UK countryside suggest that crime in rural settings is committed often by local people not urban invaders. Moreover, the very technologies deployed to reduce fear may have an anxiety effect: membership of the Text Alert Scheme provided a flow of information about suspicious movements in the vicinity which may have heightened rather than ameliorated the fear of crime.

\section{Situational measures}

Our participants' adaptations to crime, fear and the risk of victimization, shows that they combine elements of rational choice and routine activities at the common sense level 
(see Ekblom, 2013): they reveal how they have adapted to the flow of information and imagery that feeds their perceived sense of security. In relation to their properties, all of the participants put in place technical measures to modify their living environments, such as security alarms, electronic gates, high walls, guard dogs, extra lighting, and CCTV. Not all members of the community were able to afford these measures raising the question about the redistribution of security based on the relative wealth of its members (Hope, 2001).

\section{Conclusion}

\section{Summary}

Given the small scale of the study our conclusions should be read as start points rather than end points in a longer empirical project. The Janusville case reflects the way in which responsibilization strategies unfold and how crime is reflected in everyday life worlds. The closure of Garda stations in response to externally imposed austerity policies, is partly driving this adaptation. This falls short of Garland's (2001) or Burney's (2005) responsibilization as obligation as a mandate to take up task of crime control through laws or responsibility by proxy. Rather, Janusville residents reveal an adaptation closer to Zedner's (2004) responsibilization as encouragement whereby people take part in the task of providing security. When set against the wider withdrawal of state and other institutions, it is worth asking if encouragement is too soft a term, given the coercive nature of austerity driven state retraction. However, a full responsibilization is not observed from our limited study to date and hence we suggest it is more of a nuanced adaptation to late modern risk. It is less the case that our participants have developed a taste for various protection goods (Jones \& Newburn 1998; Hope 2001) as an effect in the switch in the area of crime control to private actors, but more a case that there is a reluctant adaptation to acquire security as 'grudge purchases' (Goold et al, 2010). Some members of the community we encountered expressed positive opinions about the operation and usability of the TAS scheme while others were more sceptical and mindful of its limitations. They did not express much need to receive information from the network and do not see themselves to be or to act as 'mobile sensors' (Zedner 2004).

Bauman (2007) states that the 'liquidity of norms' bolsters the role of fear as a structuring characteristic of late modernity. While such a dynamic can be observed, it is not simply the case as Janusville and its residents are also involved, with the benefits that cultural globalization brings: some the people we spoke to showed that they were networked locally and globally on their personal interests, e.g. the motorbike club. Young's (2007) characterization of late modern disembeddedness might ring true for fear and insecurity but that does not mean that it is narrowing the rural commonsense. Rural 
dwellers in Janusville defined their worldviews not by tradition or an agrarian doxa but on mass-media, social media, foreign travel, personal relationships and ties beyond community, and from personal experience and memory of city life. As Wooff (2015, p.294) observed: 'The rural is a nuanced environment, with different localities having different representations and people within those communities having different lived experiences of the police and [anti-social behaviour]'. Thus we can say that we have entered a space in which there is some degree of turmoil as people living in a rural Irish town come to grips with the withdrawal of the security presence of the state. The extent, breadth and length of this period of adaptation, and indeed resistance, is unclear but shapes the nature and scope of our research in the coming years.

\section{Doing Crime-talk Research}

In this final section we draw out our reflections on how we came to use crime-talk as a methodological approach. First we briefly outline the development of this approach form the work of Sasson (1995) and how revisions have emphasized local experience and narrative. We also briefly summarize our understanding from both how localized and thematic studies that have contributed to the development of this method and our thoughts on 'why do' crime-talk. While earlier developments have offered ways of exploring how discourse constructs the problem, our utilization of it takes place in a more dynamic relational and discursive field involving power and social transformations in respect of how the local has been transformed by global processes. Finally we provide some detail on how we entered the field to aid researchers and scholars who might wish to use a crime-talk approach.

The start point for discussing how to conduct crime-talk research is with the seminal book on the method by Theodore Sasson (1995). His analysis is set within a constructionist paradigm, centring on how social problems are framed, the identification of its causes, and the remedies proposed by citizens, commentators, experts and policy makers. Thus Sasson's main concern was how discourse shapes problems by indicating who is useful, dangerous and who is believable, without a concern for how structures transform social relations or systems of communication. Talk constructs the image of the conventional offender in America as being poor, male and black. While major empirical studies and opinion polling had shown that Americans believed that crime emanated from the urban poor and that the criminal justice system was too lenient on criminals, Sasson pointed out that citizens also believed that the best way to tackle crime was to address social problems. The academic record he suggested was too weak to account for discrepancies in these two views. Hence, Sasson (1995) sought to develop an alternative model to research the frames in which distinct American publics [our emphasis] constructed a social problem. 
Sasson's use of frame analysis rests on three key pillars. The first is that people make meaning and interpretations based on an assemblage of discourse from media, personal experiences and general popular wisdom, enabling them to ascribe blame or proffer a diagnosis. Second, public conversation is influenced by a set of wider discursive forums such as mass media and scholarly journals: the former however has more sway in shaping everyday public conversation. Third, as Sasson points out, there is a competitive arena in which these frames are fought out politically by lobbyists, activists and definers or "claim makers" who "measure their own success on this venture by the degree of visibility they win for their preferred frames (Sasson, 1995, p.10). On these key pillars his empirical platform was based upon an analysis of the performance of frames in popular and media discourses: Sasson undertook a series of peer group discussions, representative of distinct social classes; and analysed speeches by lobbyists and commentators.

Hence Sasson put forward a catalogue of five frames: faulty system (conservative discourse); blocked opportunities (liberal discourse); social breakdown (a median between liberal and conservative); media violence (based upon citizen campaigns); and racist system (civil liberties discourse). While Sasson's work provides a significant contribution to a research method for capturing the discursive construction of crime, it falls short on elaborating the competitive arenas he alluded to, where the process of filtering, classification and defining the situation takes place. Moreover, this perspective does not account for the specificities of rural locales and is based primarily on urban sensibilities.

Crime-talk can be generated by distant events at national or global scales: Sasson's work predates the acceleration in globalization, the foundation of the internet, and the information society (Castells, 2000). As Giddens (1991) pointed out, mass communications foreshortens time where events happening at a global scale can have import in local experience and constructs a sense of insecurity and fear (Young, 2007). Therefore we should not discount the impact of localised experiences when set against media accounts of events on a wider national or global scale. In this vein, Sparks, Girling and Loader (2001) suggest that the crime-talk, in fact, should be seen as place-talk. This they argue, provides a meaningful perspective in understanding victimisation and fear of crime in local settings. They observed that when they talk about crime, people refer to events and stories about experiences or those of their neighbors. Crime-talk is thus a reflection of local experience in sense making about the immediate and the proximate, and hence of the nuances of how place is being transformed by the global:

There is a dialectic in citizens' crime-talk between distance and proximity, abstractness and particularity, generic formats and localised stories, the 
known and the other which is [...] an important aspect of the diffusion and circulation of the public knowledge about crime and social order in late modern societies. (Sparks, Girling and Loader 2001, p. 887.

It appears that citizens not only construct a social problem of crime, but they use it as a basis for action in shaping their sense of self while at the same time using it as a basis of action. This effect, whether in locales or on themes, can be derived from a spectrum of studies that have sought to access accounts of the social world where people maintain the social order through linguistic devices - talk - or how identity is constructed or re-constructed through language (Potter and Wetherell, 1987). However language exists within social structures and converted into internalized social structures, or stored in the habitus to produce the right response or calls to order, as the way of acting within social structures (Bourdieu, 1991). Observing and recording crime-talk in this way gives access to a relational field (Bourdieu and Wacquant, 1992) that shows how actors create distinctions from one another; and to a discursive field of action (Rose and Miller, 1992) in which actors fashion a subjectivity by making sense of the public discourse about crime.

Willot, Griffin and Torrance (2001) utilised these approaches to discuss how upper middle class male "economic crime" offenders talked about their offences. They positioned themselves as morally superior and distinguished their actions from those of working class offenders, into whose world they had been “dragged”. Similarly Stanko's (1997) 'safety talk' utilized Garland's (1996) distinction between criminology of the self and criminology of the other when she wrote that women were expected to adapt to the the dominant framing of crime by avoiding male violence and harassment, as part of accepting the discourse about a 'high crime society'. Women's new subjectivity based upon this discursive field could be read therefore from their 'safety talk'. Stanko pointed out:

We individual women are to be taught how to move through public space, unencumbered and avoiding harassment. A woman armed is a woman forewarned. Such discourse, embedded in the language of 'the good citizen', takes additional strength in its gendered discourses of respectable femininities (Stanko, 1997, p. 492).

Access to talk is to engage with how subjects adopt technologies of the self (Rose, 1999) against a discursive field that is highly charged in respect of crime. Moreover, engaging with people's talk enables a fast engagement with the field to access how media and political discourses shape people's perceptions and actions in relation to crime, security, and safety. Crime-talk and action take place in a field of forces where various 
players seek to take positions in relation to social objects, enacted then through talk about the object (see Martin, 2011, p.317). Thus, when we access crime-talk, we are connecting to how people make sense of the discourses of crime in media and political fields.

We have pointed out that in our case, the crime rate in the region and district in which Janusville is located is lower than the national average, and our analysis reveals that a heightened emotive discourse about crime affects different categories of people in various ways. Crime-talk in low crime contexts engages with how people make sense of crime irrespective of actual rates. In Japan, where cultural constraints are cited for keeping crime low, a heightened affective insecurity is mobilized to encourage citizens to take part in crime prevention and community safety initiatives. Fenwick (2004) analysed how crime-talk in Japan is used to construct an affective insecurity, a sense of danger that stimulates responsibility. Crime control in Japan has traditionally mobilized civil society, despite the rise of bureaucratic policing and "penal modernity" (p.196). In this regard, crime-talk reflects the dispersal and penetration of a populist discourse which is imbued with the imagery of dangerous groups. In our case, mobile criminals were seen to be a particular threat in this regard, impacted greatly by the improvements in road infrastructure making access and egress easier, and locals more fearful of the consequences.

In our study, we asked people to converse with us about crime: we set up a speech event to access their experiences and thoughts about crime in the setting, relative to their wider experiences of transformation - that is, how they were affected by globalization, and whether this shaped their experiences in any way. Locals appeared to reach for a narrative of "going downhill", while exurbanites were able to compare their present experience of a rural area with a less favourable experience of city life.

We generally assume that crime-talk is unidirectional - about people making sense of media, political and expert discourses - and in doing so we presume that actors are passive sense makers, rather than collectively strategizing to protect their cultural or physical capital. A development of our approach here might be to explore localized use of information and communications technologies and social media platforms as way of generating and diffusing a discourse from the bottom up. Reserachers have analysed citizens' use of local blogs, webforums and social media for naturally occurring crimetalk. Cheshire and Wickes (2012) for example have drawn from the conversational analysis method, to identify strategies of rationalization and neutralization, where residents crafted a particular form of crime-talk, so as not to damage the prestigious reputations of their upmarket residences. Thus negative lived experiences can be strategically played down in talk to retain class distinctions. 
Finally, crime-talk analysis offers criminological researchers speedy access to the discursive and relational fields in which crime takes place. Moreover, and most crucially, it has the potential to identify how citizens themselves create a discourse in order to act on the insecurity they experiences against highly charged media and political narratives. In the case of rural crime in Ireland which we have shown, this process was driven by political and media definitions of the situation: moreover, senior police officers and their representative organizations took positions as an attempt at legitimate naming (Loader \& Mulcahy, 2001). Similarly, Bowden (2019) has shown how such position taking is a critical process in what he has defined as the security field, the space which opened up by the pluralization of policing typical of the late modern, neo-liberal policy landscape on crime control. Hence an interesting development of the crime-talk approach might be to delve into discourses and local nodal forms of security Dupont (2004) based upon security talk and security action.

\section{Postscript: Notes on the Field Research}

\section{Gatekeepers and Accessing Janusville}

While working through gatekeepers is an occupational hazard for social researchers, given that effectively they delimit what field researchers can and cannot see, maintaining good relations with them is necessary despite the limitations. (Crowhurst \& KennedyMacFoy, 2013) Accessing the issue of crime, talk about crime, safety and security is a relatively sensitive issue and hence working with a sympathetic and well positioned gatekeeper is vital. Our first attempt was unsuccessful. Having partnered with a ruralbased NGO on a European funded proposal we thought that this would be shoe-in the door. Despite the initial declaration of support, it became clear after some time that we could not count on their help to gain access to a community we had identified and discussed with them.

"Plan B" involved using social media, personal contacts, and as a desparate measure, even putting a note on a noticeboard in the busy office of one of our partners. The latter proved fruitful and underlines the power of working through personal contacts, and in using our own networks. We had two key criteria: we wished to engage with people in a rural area; and that there was a Text Alert Scheme in operation. Five potential sites meeting these criteria were identified based upon responses to our calls for access. We decided on Janusville for two main reasons: ease of access and evidence of rural change based upon new settlement as a result of commuting. Janusville was located slightly a little over a one hour drive from our base in Dublin and would allow the field researcher to make a small, but focused number of visits over the summer. 
We were keen in this preliminary case to explore a number of issues in addition to our focus on talk about crime, safety and security. Tom Inglis (2008) had identified how small rural towns and their hinterlands were being transformed by commuting, leading to new residents and divisions between the established and the newcomers. As Dublin is Ireland's major hub for its role in the global system of high-tech production in information and communications technology, we wished to see if this kind of change made a difference in narratives about crime. None of our respondents were current commuters, however. Given its close proximity to Dublin, Janusville became a popular retirement location for Dubliners seeking to live a quieter life. Our respondents were therefore a mix of those more settled and those who had more recently arrived.

Our initial gatekeeper was Barbara, who put us in contact with Ann, a local business owner, who also played a key role in helping us access potential participants for our interviews. Both of them quickly understood the nature of our research and were more than helpful in organizing the logistics of our fieldwork in Janusville.

\section{Sample}

The study is a pilot for a larger study which is now at a more advanced stage. Time and scale therefore were constraints on what we could achieve at this stage. We sought to make our sample as diversified as possible based on our reckoning that we had made contact with six potential participants. The six comprised of four participants who were participants in the crime prevention scheme Text Alert; two were non-members. Second was a range of age groups and representation of genders. Hence the youngest respondent, Eddie, was 22 at the time of conducting the interview and the oldest, Barbara, was 70. The age of the rest of the group was spread between those two ends of the spectrum.

Finally, we had a balance between newcomers and established residents. Three people were established - Dermot, Eddie and Cecilia (32, 22 and 18 years respectively) while three were more recently resident in the last seven to eight years: Ann, Fiona and Barbara. Five of this group lived in the rural countryside surrounding the town and they comprised small business owners, retirees, a civil servant, an assistant in a local shop. Our respondents were contacts of Barbara and Ann and while it made the field research possible, it imposed immediate limitations. As Barbara was a relative newcomer, she was not able to introduce us to farmers, something we have been keen to correct in subsequent fieldwork. 


\section{Endnotes}

${ }^{1}$ Janusville is a pseudonym. Similarly, all participant data subsequently used in this article are pseudonyms.

${ }^{2}$ Crime prevention programme run by An Garda Siochana and Muintir na Tire (NGO).

${ }^{3}$ An Garda Síochána is the sole Irish national police force. The name translates from Irish as 'guardians of the peace'. A Garda is singular; Gardaí plural. Commonly a Garda is referred to as 'a guard'.

${ }^{4}$ A rural-urban breakdown was available for data in 2007 but not for 2010 .

${ }^{5}$ This is commonly used to refer to the period roughly between 1995 and 2008 when Ireland achieved consistent year-on-year economic growth rates driven by high-tech industries and foreign direct investment (see for example O'Riain, 2000; Kirby 2010).

${ }^{6} \mathrm{GAA}$ is the Gaelic Athletic Association which usually has a club in each parish area. Gaelic sports include football, hurling and camogie.

${ }^{7}$ Data for district level reported crime does not include serious crimes like homicide or rape.

${ }^{8}$ Access to firearms in Ireland is strictly controlled and regulated by the Firearms Act 1925 with amendments. In order to possess a limited range of hunting and sport-shooting firearms gun owners must obtain and renew their licence every three years. Strict conditions on safety and storage of the firearm apply. 
"Crime Talk", Security and Fear in the Countryside: A Preliminary Study of a Rural Irish Town and Its Hinterland - Pytlarz and Bowden

\section{References}

Arensberg, C. M., and Kimball, S. T. ([1940] 2001). Family and community in Ireland. Ennis: CLASP Press.

Bauman, Z. (2007). Liquid times. Cambridge: Polity Press.

Beck, U. (1992). Risk society: Towards a new modernity. London: Sage.

Bell, D. (1997). Anti-idyll: rural horror. In P. Cloke \& J. Little (Eds.) Contested countryside cultures: Otherness, marginalization and rurality (pp. 94 - 108). London: Routledge.

Bourdieu, P. (1991). Language and Symbolic Power. Cambridge: Polity.

Bourdieu, P., \& Wacquant, L. J. D. (1992). An Invitation to Reflexive Sociology. Cambridge: Polity.

Bowden, M. (2019). The security field: Forming and expanding a Bourdieusian criminology. Criminology \& Criminal Justice, [ahead of print]. https://doi.org/10.1177/1748895819839734

Burney, E. (2005). Making people behave. Anti-social behaviour, politics and policy. Cullompton: Willan Publishing.

Cabras, I. \& Mount, M. (2016). Economic development, entrepreneurial embeddedness and resilience: The case of pubs in rural Ireland. European Planning Studies, 24, 254-76. https://doi.org/10.1080/09654313.2015.1074163

Carrington, K., Hogg, R., McIntosh, A \& Scott, J. (2012). Crime talk, FIFO workers and cultural conflict on the mining boom frontier. Australian Humanities Review, 53, $1-14$.

Castells, M. (2000). The rise of the network society (2nd ed.). Oxford: Blackwell.

Ceccato, V., \& Dolmen, L. (2011). Crime in rural Sweden. Applied Geography 31, 119135. https://doi.org/10.1016/j.apgeog.2010.03.002

Ceccato, V., \& Dolmen, L. (2013). Crime prevention in rural Sweden. European Journal of Criminology 10, 89-112. https://doi.org/10.1177/1477370812457763 
Central Statistics Office (2007). Crime and victimisation quarterly national household survey 2006 (including results for 1998 and 2003). Dublin: Central Statistics Office Retrieved from:

http://www.cso.ie/en/media/csoie/releasespublications/documents/crimejustice/20 06/crimevictimisation_qnhs2006.pdf.

Central Statistics Office (2010a). Census of agriculture 2010 - final results. dublin: Central Statistics Office Retrieved from: http://www.cso.ie/en/media/csoie/releasespublications/documents/agriculture/201 0/full2010.pdf.

Central Statistics Office (2010b). Crime and victimisation. quarterly national household survey 2010. Dublin: Central Statistics Office Retrieved from: http://www.cso.ie/en/media/csoie/releasespublications/documents/crimejustice/20 10/qnhscrimeandvictimisation2010.pdf.

Central Statistics Office (2011). Census 2011. Preliminary results. Dublin: Central Statistics Office Retrieved from: http://www.cso.ie/census/table8.htm.

Chaplin, H., \& Matthews, A. (2005) Reform of eu sugar regime: impact on sugar production in ireland. Dublin: IIIS Discussion Paper. https://doi.org/10.2139/ssrn.922066

Chalfin, A., \& McCrary, J. (2012). The effect of police on crime: new evidence from u.s. cities, 1960-2010. Retrieved from: http://eml.berkeley.edu// jmccrary/chalfin_mccrary2012.pdf.

Cheshire, L., \& Wickes, R. (2012). Crime talk in the suburbs: symbolic representations of status and security on a master planned estate. Housing Studies, 27(8), 1162-1181. https://doi.org/10.1080/02673037.2012.728573

Cohen, L., Manion, L., \& Morrison, K. (2011). Research methods in education. Oxon: Routledge.

Conaway, M.R., \& Lohr, S.L. (1994). A longitudinal analysis of factors associated with reporting violent crimes to the Police. Journal of Quantitative Criminology, 10, 23-39. https://doi.org/10.1007/BF02221007 
"Crime Talk", Security and Fear in the Countryside: A Preliminary Study of a Rural Irish Town and Its Hinterland - Pytlarz and Bowden

Crowhurst, I., \& Kennedy-MacFoy, M. (2013). Troubling gatekeepers: methodological considerations for social research. International Journal of Social Research Methodology, 16(6), 457-462. https://doi.org/10.1080/13645579.2013.823281

Cusack, J. (2013, March 31). Crime surge leaves rural Ireland in total despair. Independent.ie Retrieved from: http://www.independent.ie/irish-news/crimesurge-leaves-rural-ireland-in-total-despair-29165118.html.

D’Arcy, C. (2015) 'One million messages sent using Garda Text Alert Scheme', Irish Times online edition http://www.irishtimes.com/news/crime-and-law/one-millionmessages-sent-using-garda-text-alert-system-1.2052940 accessed 21 September 2016.

DeKeseredy, W.S., Donnermeyer, J.F., \& Schwartz, M.D. (2009). Toward a gendered second generation CPTED for preventing woman abuse in rural communities. Security Journal, 22, 178-189. https://doi.org/10.1057/sj.2009.3

Department of Justice, Equality and Law Reform (2009). Fear of crime in Ireland and its impact on quality of life. Dublin: Department of Justice, Equality and Law Reform Retrieved from:

http://www.justice.ie/en/JELR/Fear\%20of\%20Crime\%20in\%20Ireland.pdf/Files/ Fear\%20of\%20Crime\%20in\%20Ireland.pdf

Donnermeyer J.F. \& Barclay, E. (2005) The policing of farm crime. Police Practice and Research. An International Journal, 6, 3-17. https://doi.org/10.1080/15614260500046913

Donnermeyer, J. F., \& DeKeseredy, W. S. (2014). Rural Criminology. Oxon: Routledge. https://doi.org/10.4324/9780203094518

Donnermeyer, J. F., Scott, J., \& Barclay, E. (2013). How rural criminology informs critical thinking in criminology. International Journal for Crime, Justice and Social Democracy, 2, 69-91. https://doi.org/10.5204/ijcjsd.v2i3.122

Dupont, B. (2004). Security in the age of networks. Policing and Society, 14(1), 76-91. https://doi.org/10.1080/1043946042000181575

Ekblom, P. (2013). Situational crime prevention. In E. McLaughlin \& J. Muncie The Sage Dictionary of Criminology 3rd Edition. London: SAGE. 
Evans, C.B.R., Smokowski, P.R. \& Cotter, K.L. (2014). Cumulative bullying victimization: An investigation of the dose-response relationship between victimization and the associated mental health outcomes, social supports, and school experiences of rural adolescents. Children and Youth Services Review, 44, 256-264. https://doi.org/10.1016/j.childyouth.2014.06.021

Fenwick, M. (2004). 'Crime talk' and crime control in contemporary urban japan. In J. Ferrell, K. Hayward, W. Morrison, \& M. Presdee (Eds.), Cultural Criminology Unleashed (pp. 193203). London: Glasshouse.

Foucault, M. (1977). Discipline and punish: The birth of the prison. London: Penguin.

Garland, D. (1996). The Limits of the sovereign state: strategies of crime control in contemporary society. British Journal of Criminology, 36, 347-375. https://doi.org/10.1093/oxfordjournals.bjc.a014105

Garland, D. (2000). The culture of high crime societies: some preconditions of recent law and order policies. British Journal of Criminology, 40, 347-345. https://doi.org/10.1093/bjc/40.3.347

Garland, D. (2001). The culture of control: crime and social order in contemporary society. Oxford: Oxford University Press. https://doi.org/10.7208/chicago/9780226190174.001.0001

Gerber, M., Hirtenlehner, H., Jackson, J. (2010). Insecurities about crime in Germany, Austria and Switzerland. European Journal of Criminology, 7, 141-157. https://doi.org/10.1177/1477370809356871

Giddens, A. (1991). The consequences of modernity. Cambridge: Polity.

Gkartzios, M \& Scott, M (2012). 'Gentrifying the rural? Planning and market processes in rural Ireland', International Planning Studies, 17, 253-76. https://doi.org/10.1080/13563475.2012.696476

Goold, B., Loader, I. \& Thumala, A. (2010). Consuming security: tools for a sociology of security consumption. Theoretical Criminology, 14, 3-30. https://doi.org/10.1177/1362480609354533

Hogg, R., \& Carrington, K., (2006). Policing the rural crisis. Sydney: The Federation Press. 
"Crime Talk", Security and Fear in the Countryside: A Preliminary Study of a Rural Irish Town and Its Hinterland - Pytlarz and Bowden

Hope, T. (2001). Inequality and the clubbing of private security. In T. Hope, \& R. Sparks (Eds.) Crime, Risk and Insecurity. London: Routledge.

Hope, T. (2009). The political evolution of situational crime prevention in England and Wales. In A. Crawford Crime prevention policies in comparative perspective. Cullompton: Willan Publishing.

Hudson, B. (2001). Punishment rights and difference: Defending justice in the risk society. In K. Sevenson \& R.R. Sullivan Crime, risk and justice: The politics of crime control in liberal democracies. Devon: Willan Publishing.

Hughes, G. (2007). The politics of crime and community. New York: Palgrave Macmillan.

Inglis, T. (2008). Global Ireland: Same difference. New York: Routledge. https://doi.org/10.4324/9780203934005

Irish Farmers Association (2016). Public urged to combat farm related thefts. Dublin: Irish Farmers Association (Retrieved from: http://www.ifa.ie/public-urged-tocombat-farm-related-thefts/\#.WBB2QvkrK2x)lea

Jackson, J., \& Bradford, B. (2009). Crime, policing and social order: on the expressive nature of public confidence in policing. British Journal of Sociology 60, 493-521. https://doi.org/10.1111/j.1468-4446.2009.01253.x

Jones, T., Newburn, T. (1998). Private security and public policing. Oxford: Clarendon Press.

Keohane, K., \& Kuhling, C. (2003). Millenarianism, utopianism and the new Ireland: The tragedy (and comedy) of accelerated modernisation. In C. Coulter \& S. Coleman (Eds.), The End of Irish History? Critical Reflection on the Celtic Toger. Manchester: University Press.

Kitchin, R., O'Callaghan, C., \& Gleeson, J. (2012). Unfinished estates in post-Celtic Tiger Ireland (NIRSA) Working Paper Series. No. 62 Working Paper. NIRSA National Institute for Regional and Spatial Analysis. (Retrieved from: http://eprints.maynoothuniversity.ie/3578/1/RK_Unfinished_Estates.pdf). 
Lee, M. (2007). Inventing fear of crime: Criminology and the politics of anxiety. Cullompton: Willan.

Loader, I., \& Mulcahy, A. (2001). The power of legitimate naming: part ii - making sense of the elite police voice. British Journal of Criminology, 41, 252-265. https://doi.org/10.1093/bjc/41.2.252

MacConnell, E. (2012, December 10). Garda cuts 'leave rural area at risk of crime'. Irish Examiner. Retrieved from: http://www.irishexaminer.com/ireland/garda-cutsstensonve-rural-area-at-risk-of-crime-216504.html.

McGee, H. (2015, September 24). Analysis: Election ensures rural crime stays on agenda. The Irish Times. Retrieved from: http://www.irishtimes.com/news/politics/analysis-election-ensures-rural-crimestays-on-agenda-1.2363988

McLaughlin, E. (2007). The new policing. London: SAGE.

McLaughlin, E. (2013). Fear of crime. In E. McLaughlin \& J. Muncie The Sage Dictionary of criminology 3rd Edition. London: SAGE.

McKeown, K., \& Brosnan, M. (1998). Police and community: An evaluation of neighbourhood watch and community alert in Ireland. Retrieved from: http://inis.gov.ie/en/JELR/neighbwatch.pdf/Files/neighbwatch.pdf.

Meredith, D., \& Faulkner, J.P. (2014). The nature of uneven economic development in Ireland: 1991 - 2011. In G. Kearns, D. Meredith \& J. McDonagh (Eds.), Spatial justice and Ireland's economics crisis. Dublin: Royal Irish Academy.

Martin, L.J. (2011). The explanation of social action. Oxford: Oxford University Press. https://doi.org/10.1093/acprof:oso/9780199773312.001.0001

Murphy, E \& Scott, M (2013). Mortgage-related issues in a crisis economy: Evidence from rural households in Ireland, Geoforum, 46, 34-44. https://doi.org/10.1016/j.geoforum.2012.12.003

Mythen, G. (2014). Understanding the risk society. Crime, security and justice. Basingstoke: Palgrave Macmillan.

Newburn, T. (2013). Criminology. London: Routledge. 
"Crime Talk", Security and Fear in the Countryside: A Preliminary Study of a Rural Irish Town and Its Hinterland - Pytlarz and Bowden

O'Hagan, B. (2012, June 10). Rural Ireland under crime siege. Independent.ie Retrieved from: http://www.independent.ie/irish-news/rural-ireland-under-crime-siege26862914.html.

Potter, J., \& Wetherell, M. (1987). Discourse and social psychology: beyond attitudes and behaviour. London: Sage.

Rose, N. (1999). Powers of freedom: reframing political thought. Cambridge: Cambridge University Press. https://doi.org/10.1017/CBO9780511488856

Rose, N., \& Miller, P. (1992). Political power beyond the state: problematics of government. British Journal of Sociology, 43(2), 173-205. https://doi.org/10.2307/591464

Ross, C., Mirowski, J., \& Pribesh, S. (2001). Powerlessness and the amplification of threat: neighbourhood disadvantage, disorder and mistrust. American Sociological Review, 66, 568-91. https://doi.org/10.2307/3088923

Sasson, T. (1995). Crime Talk: How citizens construct a social problem. New York: de Gruyter.

Scott. J., Carrington K., \& McIntosh, A. (2012). Established-outsider relations and fear of crime in mining towns. Sociologia Ruralis 52, 147-169. https://doi.org/10.1111/j.1467-9523.2011.00557.x

Shearing, C., \& Wood, J. (2003). Nodal governance, democracy, and the new 'denizens'. Journal of Law and Society, 30, 400-419. https://doi.org/10.1111/14676478.00263

Somerville, P., Smith, R. \& McElwee, G. (2015). The dark side of rural idyll: Stories of illegal/illicit economic activity in the UK countryside. Journal of Rural Studies, 39, 219-228. https://doi.org/10.1016/j.jrurstud.2014.12.001

Sparks, R., Girling, E., \& Loader, I. (2001). Fear and everyday urban lives. Urban Studies, 38(56), 885-898. https://doi.org/10.1080/00420980123167

Stanko, E. A. (1997). Safety Talk: conceptualizing women's risk assessment as a 'technology of the soul'. Theoretical Criminology, 1(4), 479-499. https://doi.org/10.1177/1362480697001004004 
Stenson, K., \& Lea, J. (2007). Security, sovereignty and non-state governance 'from below'. Canadian Journal of Law and Society, 22, 9-27. https://doi.org/10.1017/S0829320100009339

Takahashi, Y. (2010). Creating a crime-resistant society in Japan: maintaining public safety with community resources. Japanese Studies Association Journal, 8, 179195.

Tierney, D. (2016, March 17). Deal demands better focus on rural Ireland initiatives. Connacht Tribune. Retrieved from: http://connachttribune.ie/deal-demands-betterfocus-on-rural-ireland-initiatives-436/

van Hout, M-C (2009). Youth alcohol and drug use in rural Ireland - parent's view. Rural and remote health 9,1171.

Warburton, J, Scharf, T \& Walsh, K (2016). 'Flying under the radar? Risks of social exclusion for older people in rural communities in Australia, Ireland and Northern Ireland', Sociologia Ruralis, epub ahead of print. https://doi.org/10.1111/soru.12129

Websdale, N. (1998). Rural woman battering and the justice system: An ethnography. Thousand Oaks: Sage.

Wells, L.E., \& Weisheit, R.A. (2004). Patterns of rural and urban crime: A county-level comparison. Criminal Justice Review 29, 1-21. https://doi.org/10.1177/073401680402900103

Willott, S., Griffin, C., \& Torrance, M. (2001). Snakes and ladders: upper-middle class male offenders talk about economic crime. Criminology, 39(2), 441-466. https://doi.org/10.1111/j.1745-9125.2001.tb00929.x

Wooff, A. (2015). Relationships and responses: Policing anti-social behaviour in rural Scotland. Journal of Rural Studies, 39, 287-295. https://doi.org/10.1016/j.jrurstud.2014.11.003

Zedner L. (2004). Criminal justice. Oxford: Oxford University Press. 
"Crime Talk", Security and Fear in the Countryside: A Preliminary Study of a Rural Irish Town and Its Hinterland - Pytlarz and Bowden

Yarwood, R. \& Wooff, A. (2016). Policing the countryside in a devolving UK. In Donnermmeyer, J.F. (Ed.) The Routledge International Handbook of Rural Criminology. (pp.374-386). London: Routledge. https://doi.org/10.4324/9781315755885-42

Young, J. (2007). The vertigo of late modernity. London: Sage. 